\title{
Association of late-life depression with cognitive impairment: evidence from a cross-sectional study among older adults in India
}

T. Muhammad*i(D) and Trupti Meher

\begin{abstract}
Background: Late-life depression (LLD) is considered as a prodrome to dementia and plays a major role in the development of long-term cognitive disabilities. We aimed to estimate the prevalence and correlates of LLD and cognitive impairment and to explore their associations among older adults in India.

Methods: Data for this study was derived from the Longitudinal Ageing Study in India (LASI) Wave 1 (2017-18). The total sample included 31,464 (15,098 male and 16,366 female) older individuals aged 60 years and above. Cognitive impairment measured from various domains derived from the cognitive module of the Health and Retirement Study (HRS), and major depression measured by the CIDI-SF (Composite International Diagnostic Interview- Short Form) were the outcome variables. Descriptive, bivariate, and multivariable analyses were performed to fulfill the objectives of the study.

Results: The overall prevalence of LLD and cognitive impairment for the current sample was $8.7 \%$ and $13.7 \%$ respectively. Among older individuals who have rated their health status as poor were 2.59 times more likely to suffer from LLD [OR: 2.59, Cl: 2.24-2.99] as compared to their counterparts. The older adults who had difficulty in activities of daily living (ADL) and instrumental activities of daily living (IADL) were $74 \%$ and $69 \%$ more likely to suffer from LLD. Similarly, older adults who were depressed had higher odds of cognitive impairment [OR: 1.22, Cl: 1.01-1.48] compared to their counterparts. Also, older adults who were depressed and belonged to rural areas were 2.58 times [AOR: 2.58, Cl: 1.95-3.41] more likely to be cognitively impaired than those who were not depressed and resided in urban areas.

Conclusions: Depression is linked to an increased risk of cognitive decline and dementia; therefore, failing to diagnose and treat LLD in later life may have significant health implications. Moreover, treatment under the care of a cognitive neurologist or geriatric psychiatrist is recommended for people with LLD and cognitive disability due to both the disorders' complex existence.
\end{abstract}

Keywords: Depression, Cognitive impairment, Older adults, India

*Correspondence: muhammad@iips.net; muhammad.iips@gmail.com International Institute for Population Sciences, 400088 Mumbai, Maharashtra, India

(c) The Author(s). 2021 Open Access This article is licensed under a Creative Commons Attribution 4.0 International License, which permits use, sharing, adaptation, distribution and reproduction in any medium or format, as long as you give appropriate credit to the original author(s) and the source, provide a link to the Creative Commons licence, and indicate if changes were made. The images or other third party material in this article are included in the article's Creative Commons licence, unless indicated otherwise in a credit line to the material. If material is not included in the article's Creative Commons licence and your intended use is not permitted by statutory regulation or exceeds the permitted use, you will need to obtain permission directly from the copyright holder. To view a copy of this licence, visit http://creativecommons.org/licenses/by/4.0/ The Creative Commons Public Domain Dedication waiver (http://creativecommons.org/publicdomain/zero/1.0/) applies to the data made available in this article, unless otherwise stated in a credit line to the data. 


\section{Introduction}

In an aging population, cognitive impairment is not only a major risk factor for ill health, but it also places a significant burden on public health [1]. It is common in late life and may be caused by aging and associated physical or psychological disorders [2]. Cognitive impairment and dementia result in a gradual and devastating reduction in most physical abilities, functional independence, and social relationships. The global dementing population has been growing and is expected to reach 131.5 million by 2050 [3]. Further, dementia is expected to rise from $58 \%$ in 2010 to $63 \%$ in 2030 and $71 \%$ by 2050 in low and middle-income countries [4].

Depression, on the other hand, is a highly prevalent psychiatric disorder among the older population and is the most frequent cause of emotional suffering in later years of life $[5,6]$. Late-life depression (LLD) is a significant public health concern as it leads to functional decline, physical disability, and increased health care usage $[7,8]$. It negatively impacts physical and psychological health and quality of life $[9,10]$. As per epidemiological data, about $11-35 \%$ of older adults experience clinically significant depressive symptoms $[5,11]$. However, these rates are even higher in clinical settings [12]. Depressive symptoms are more frequent among the oldest old population, but the higher frequency is explained by the factors like aging, physical disability, and cognitive impairment $[5,13]$. Nevertheless, from a diagnostic perspective, LLD is often under-recognized, under-reported, and under-treated [14].

A growing body of literature suggests that depression is a prodrome to dementia and plays a major role in the development of long-term cognitive disabilities [15]. Individuals with LLD frequently present with several cognitive complaints in the clinical environment, and it is estimated that $20-50 \%$ of older adults with LLD have cognitively impaired abilities [16, 17]. Depression and cognitive impairment are estimated to co-occur among $25 \%$ of older individuals aged 85 and above [18]. According to Kingston et al. [19], over the next two decades, the proportion of older adults with both cognitive impairment and depressive symptoms will increase. The relationship between depression and cognitive impairment is however complicated. Depressive symptoms frequently lead to complaints about deteriorating cognitive function, and cognitive deficiencies lead to complaints about depression [20, 21]. As a result, determining whether depression causes cognitive deterioration or cognitive impairment leads to depression is often difficult [22].

Several studies have reported that people with LLD do worse in their cognitive functioning than the people who are not depressed, with working memory, executing skills, and information processing capacity being the most frequently affected [23, 24]. It has also been observed that many older adults who are cognitively affected after a depressive disorder continue to be cognitively disabled even after the illness has passed [25]. Nevertheless, depressive symptoms may result in the progression of mild cognitive impairment to dementia [26]. LLD has been linked to an elevated risk of dementia, including Parkinson's disease and Alzheimer's disease, according to research [27, 28]. On the other hand, LLD in many cases is also considered to have a significant negative impact on the overall functioning of older individuals, giving rise to the controversial condition of 'pseudodementia' [29].

In India, little is known about the prevalence of depression and cognitive impairment in older adults. However, most of the research in this field is confined to a limited geographical context and consequently, sample sizes are small to yield precise estimates. Older individuals with impaired cognitive function often have more than one risk factor. It is important to identify those risk factors and determine their association with cognitive impairment especially in the Indian context where illiteracy exists on an appalling scale. Therefore, we aimed to estimate the prevalence of LLD and cognitive impairment among older adults aged 60 and above. Furthermore, it was of interest to explore the relationship between LLD and cognitive impairment among the older population in India.

\section{Methods}

\section{Data source}

Data for this study was derived from the Longitudinal Ageing Study in India (LASI) Wave 1 (2017-18) [30]. The LASI is a full-scale national survey of scientific investigation of the health, economic, and social determinants and consequences of population aging in India. This nationally representative survey included over 72 , 000 older adults aged 45 and above and their spouses irrespective of their ages, across all states and union territories in India. The survey adopted a multistage stratified area probability cluster sampling design to arrive at the eventual units of observation: older adults aged 45 and above. It was conducted with a three-stage sampling design in rural areas and a four-stage sampling design in urban areas. In each state/UT, the first stage involved the selection of Primary Sampling Units (PSUs), that is, sub-districts (Tehsils/Talukas), and the second stage involved the selection of villages in rural areas and wards in urban areas in the selected PSUs. In rural areas, households were selected from selected villages in the third stage. However, sampling in urban areas involved an additional stage. Specifically, in the third stage, one Census Enumeration Block (CEB) was randomly selected in each urban area and in the fourth stage, households 
were selected from this CEB. The detailed methodology with the complete information on the survey design and data collection was published in the survey report [30]. The present study focused on the eligible respondents aged 60 years and above. The total sample size for the present study was 31,464 (15,098 male and 16,366 female) older individuals aged 60 years and above.

\section{Outcome variables}

There were two outcome variables used in the study. Both the outcome variables were dichotomized in the analyses.

1. Cognitive impairment was measured through five broad domains (memory, orientation, arithmetic function, executive function, and object naming). The cognitive measures in the LASI were derived from The University of Michigan Health and Retirement Study (HRS). Memory was measured using immediate word recall (0-10 points) and delayed word recall (0-10 points); orientation was measured using the time ( $0-4$ points) and place ( $0-4$ points) measure; arithmetic function was measured through backward counting ( $0-2$ points), serial seven ( $0-5$ points), and computation method (0-2); executive function was measured through paper folding (0-3) and pentagon drawing method (0-1); and finally, an object naming was conducted (0-2) among the study participants. A composite score of 0-43 was computed using the domain-wise measure with a higher score representing better cognitive functioning. The lowest 10th percentile is used as a proxy measure of cognitive impairment [30]. In our study, the respondents who received assistance during the cognition module were excluded from the analysis.

2. The major depression among the older adults with symptoms of dysphoria was calculated using the CIDI-SF (Composite International Diagnostic Interview-Short Form) with a score of 3 or more out of 10 symptoms (as the lowest 10th percentile is used as a proxy measure of major depression among older adults) leading to a 0.55 Probability of CIDI caseness of major depression. However, a cut-off of 5/10 symptoms (0.89 Probability of CIDI caseness of major depression) and 7/10 symptoms (0.91 Probability of CIDI caseness of major depression) had also been chosen for the sensitivity analyses in the present study (results given in the supplementary file). The scale estimates a probable psychiatric diagnosis of major depression and has been validated in field settings especially by non-clinicians in general population surveys and widely used in population-based health surveys [31]. Cronbach's alpha indicated that CIDI-SF has excellent reliability $(\alpha=0.8)$.
The questions which were used to assess the depression were as follow:

1. During the last 12 months, was there ever a time when you felt sad, blue, or depressed for two weeks or more in a row?

2. Please think of the two weeks during the last 12 months when these feelings were worst. During that time, did the feelings of being sad, blue, or depressed usually last all day long, most of the day, about half the day, or less than half the day?

3. During those two weeks, did you feel this way every day, almost every day, or less often than that?

4. Did you lose interest in most things?

5. Did you ever feel more tired out or low in energy than is usual for you?

6. Did you lose your appetite?

7. During the same two-week period, did you have a lot more trouble concentrating than usual?

8. People sometimes feel down on themselves and no good or worthless. During those two weeks, did you feel this way?

9. Did you think a lot about death - either your own, someone else's, or death in general - during those two weeks?

10. Did you have more trouble falling asleep than you usually do during those two weeks?

\section{Explanatory variables}

1. Age was coded as 'young old' (60-69 years), 'oldold (70-79 years), and 'oldest-old ( $80+$ years).

2. Sex was coded as 'male' and 'female'.

3. Educational status was coded as 'no education/ primary not completed', 'primary', 'secondary', and 'higher'.

4. Marital status was recoded as 'currently in marital union' and 'not in a marital union' which includes 'never married, divorced, separated \& widowed.

5. Working status was coded as 'never/not working', 'currently working', and 'retired'.

6. Living arrangement was recoded as 'alone', 'with spouse', and 'others'.

7. Community involvement was measured through the question "Are you a member of any of the organizations, religious groups, clubs, or societies? And it was recoded as 'no' for no community involvement and 'yes' for representing community involvement.

8. Physical activity status was assessed through the question "How often do you take part in sports or vigorous activities, such as running or jogging, swimming, going to a health center or gym, cycling, or digging with a spade or shovel, heavy lifting, 
chopping, farm work, fast bicycling, cycling with loads?" the responses were recoded as 'yes' (every day, more than once a week, once a week, one to three times in a month), and 'no' (never) [30].

9. Self-rated health was coded as 'good' which includes very good, good, and fair; whereas, 'poor' includes poor and very poor [32].

10. Activities of Daily Living (ADL) is a term used to refer to normal daily self-care activities (such as movement in bed, changing position from sitting to standing, feeding, bathing, dressing, grooming, personal hygiene, etc.). The ability or inability to perform ADLs is used to measure a person's functional status, especially in the case of people with disabilities and the ones in their older ages [33]. It is coded as 'no' and 'yes' representing having difficulty in ADL.

11. Difficulty in IADL (Instrumental Activities of Daily Living) was coded as 'no' and 'yes'. Activities of daily living that are not necessarily related to the fundamental functioning of a person, but they let an individual live independently in a community. These tasks are necessary for independent functioning in the community. Respondents were asked if they were having any difficulties that were expected to last more than three months, such as preparing a hot meal, shopping for groceries, making a telephone call, taking medications, doing work around the house or garden, managing money (such as paying bills and keeping track of expenses), and getting around or finding an address in unfamiliar places [34].

12. The monthly per capita consumption expenditure (MPCE) quintile was assessed using household consumption data. Sets of 11 and 29 questions on the expenditures on food and non-food items, respectively, were used to canvas the sampled households. Food and non-food expenditures have been standardized to the 30-days reference period. The MPCE is computed and used as the summary measure of consumption. The variable was then divided into five quintiles i.e., from poorest to richest.

13. Religion was recoded as 'Hindu', 'Muslim', and 'Others'.

14. Caste was recoded as 'Scheduled Caste/Scheduled Tribe' (SC/ST), 'Other Backward Class' (OBC), and 'Others'.

15. Place of residence was coded as 'rural' and 'urban'.

16. The regions of India were coded as 'North', 'Central', 'East', 'Northeast', 'West', and 'South' [35].

\section{Statistical analyses}

Descriptive statistics along with cross-tabulation were presented in the present study. Additionally, binary logistic regression analyses [36] were performed to establish the association between the outcome variables and explanatory variables.

The binary logistic regression model is usually put into a more compact form as follows:

$$
\operatorname{Logit}[\mathrm{P}(\mathrm{Y}=1)]=\beta_{0}+\beta * \mathrm{X}
$$

The parameter $\beta_{0}$ estimates the log odds of cognitive impairment for the reference group, while $\beta$ estimates the maximum likelihood, the differential log odds of major depression and cognitive impairment associated with a set of predictors $X$, as compared to the reference group.

Model-1 provides the estimates of cognitive impairment by major depression and is adjusted for all other explanatory variables in the study. Model-2 which is adjusted for all the covariates represents the interaction effect [37-39] of major depression with the place of residence on cognitive impairment among older adults to find out the rural-urban gradient in the association of depression and cognitive impairment.

The complex survey design effects were adjusted by using STATA svyset and svy commands. The whole statistical analyses were performed by using STATA version 14 [40].

\section{Results}

\section{Socio-demographic profile of the study participants}

Table 1 represents the socio-demographic profile of the older adults aged 60 and above in India. The share of the young-old population was nearly $59 \%$ while the share of the old-old and oldest-old population was around 30 and $11 \%$ respectively. In the study sample, about $53 \%$ of the older adults were females. Nearly $68 \%$ of the older adults were illiterate or their primary education was incomplete, whereas, only $7 \%$ were highly educated. Besides, around $30 \%$ of the study participants belonged to urban areas against $70 \%$ who were rural residents.

\section{Bivariate and logistic regression analyses of LLD among older adults}

Table 2 gives a representation of the bivariate and logistic regression estimates for LLD among older adults. The overall prevalence of LLD in this sample was $8.7 \%$. Nearly $11 \%$ of elderly aged 80 and above were suffering from LLD against $8.4 \%$ of older adults aged $60-69$ of which the Chi2 test showed no significance. The prevalence rate of LLD was greater among females (9.7\%) than the males $(7.5 \%)$. The percentage of LLD was highest among older adults with less education (9.5\%). Further, more than $10 \%$ of older adults with LLD were not 
Table 1 Socio-economic profile of the study sample

\begin{tabular}{|c|c|c|}
\hline Background Factors & Sample & Percentage \\
\hline \multicolumn{3}{|l|}{ Age (in years) } \\
\hline Young old (60-69) & 18,410 & 58.5 \\
\hline Old old (70-79) & 9,501 & 30.2 \\
\hline Oldest old (80+) & 3,553 & 11.3 \\
\hline \multicolumn{3}{|l|}{ Sex } \\
\hline Male & 14,931 & 47.5 \\
\hline Female & 16,533 & 52.6 \\
\hline \multicolumn{3}{|l|}{ Education } \\
\hline No education/primary not completed & 21,381 & 68 \\
\hline Primary & 3,520 & 11.2 \\
\hline Secondary & 4,371 & 13.9 \\
\hline Higher & 2,191 & 7 \\
\hline \multicolumn{3}{|l|}{ MPCE quintile } \\
\hline Poorest & 6,829 & 21.7 \\
\hline Poorer & 6,831 & 21.7 \\
\hline Middle & 6,590 & 21 \\
\hline Richer & 6,038 & 19.2 \\
\hline Richest & 5,175 & 16.5 \\
\hline \multicolumn{3}{|l|}{ Religion } \\
\hline Hindu & 25,871 & 82.2 \\
\hline Muslim & 3,548 & 11.3 \\
\hline Others & 2,045 & 6.5 \\
\hline \multicolumn{3}{|l|}{ Caste } \\
\hline SC/ST & 8,505 & 27.1 \\
\hline $\mathrm{OBC}$ & 14,231 & 45.2 \\
\hline Others & 8,729 & 27.7 \\
\hline \multicolumn{3}{|l|}{ Place of residence } \\
\hline Rural & 22,196 & 70.6 \\
\hline Urban & 9,268 & 29.5 \\
\hline \multicolumn{3}{|l|}{ Region } \\
\hline North & 3,960 & 12.6 \\
\hline Central & 6,593 & 21 \\
\hline East & 7,439 & 23.6 \\
\hline Northeast & 935 & 3 \\
\hline West & 5,401 & 17.2 \\
\hline South & 7,136 & 22.7 \\
\hline Total & 31,464 & 100 \\
\hline
\end{tabular}

MPCE Monthly per capita consumption expenditure; $A D L$ Activities of daily living; IADL Instrumental activities of daily living

in a marital union. Nearly $13.5 \%$ of the older adults who lived alone reported suffering from LLD.

Moreover, multi-variable analysis shows that the oldest old participants were $20 \%$ less likely to suffer from LLD [OR: 0.80, CI: 0.62-1.04] in comparison to the youngold adults. The older adults who were not in a marital union were $21 \%$ more likely to suffer from depression in late life [OR: 1.21, CI: 1.02-1.44] in comparison to the older adults who were currently married. Notably, the odds of depression were lower among older adults who lived with their children and others [OR: 0.72, CI: 0.550.94] with respect to the older adults who lived alone. The older adults who were economically active or retired were 19 and $29 \%$ significantly more likely to suffer from LLD in comparison to the older adults who were economically inactive. Among older individuals who have rated their health status as poor were 2.59 times more likely to suffer from LLD [OR: 2.59, CI: 2.24-2.99] as compared to their counterparts. The older adults who had difficulty in ADL and IADL were 74\% [OR: 1.74, CI: 1.45-2.08] and 69\% [OR: 1.69, CI: 1.43-2.01] significantly more likely to suffer from LLD in comparison to the older adults who had no ADL and IADL difficulty respectively. Interestingly, the odds of depression were significantly higher among the older adults who belonged to the highest MPCE quintile [OR: 1.34, CI: 1.09-1.64] in reference to the older people who were from the poorest MPCE quintile. Besides, urban dwellers had lower odds of suffering from LLD [OR: 0.83, CI: 0.70-0.98] compared to their rural counterparts.

\section{Percentage of depressed and cognitively impaired older adults by age, sex, and place of residence}

Figure 1 depicts the percentage of cognitive impairment among older adults who were depressed by their age and place of residence. In the case of both urban and rural areas, the oldest old individuals aged 80 and above had the highest percentage of cognitive impairment compared to all other age groups.

Figure 2 reveals the percentage of cognitive impairment among older adults who were depressed by their sex and place of residence. Among urban dwellers, $12.1 \%$ males were cognitively impaired against $8.6 \%$ females whereas, in the case of rural areas, females (13.8\%) had shown a greater percentage for cognitive impairment.

\section{Bivariate analyses and logistic regression estimates of cognitive impairment among older adults}

Table 3 depicts the share of older adults who suffered from cognitive impairment. According to the analysis, the prevalence of cognitive impairment for the current sample was $13.7 \%$. It was found that around $18 \%$ of the older adults who were depressed also suffered from cognitive impairment while $17 \%$ of the older adults suffering from cognitive impairment were rural residents. About $28 \%$ of the oldest-old individuals were suffering from cognitive impairment. Older women had a substantially higher percentage of cognitive impairment $(20 \%)$ than men $(7.1 \%)$.

In the logistic regression analysis, it was found that the older adults who were depressed were $22 \%$ significantly 
Table 2 Bivariate and logistic regression estimates for major depression among older adults in India

\begin{tabular}{|c|c|c|c|}
\hline Variables & $\%$ & $p<0.05$ & AOR $(95 \% \mathrm{Cl})$ \\
\hline \multicolumn{4}{|l|}{ Age (in years) } \\
\hline Young old (60-69) & 8.41 & & Ref. \\
\hline Old old (70-79) & 8.42 & & $0.788^{* * *}(0.676-0.918)$ \\
\hline Oldest old (80+) & 10.79 & & $0.805^{*}(0.623-1.040)$ \\
\hline Sex & & * & \\
\hline Male & 7.5 & & Ref. \\
\hline Female & 9.71 & & $1.136(0.967-1.333)$ \\
\hline Educational status & & * & \\
\hline No/primary education & 9.55 & & Ref. \\
\hline Secondary & 6.39 & & $0.903(0.745-1.095)$ \\
\hline Higher & 5.56 & & $0.771(0.561-1.059)$ \\
\hline Marital status & & * & \\
\hline Currently in union & 7.77 & & Ref. \\
\hline Not in union & 10.13 & & $1.211^{* *}(1.020-1.438)$ \\
\hline Living arrangement & & * & \\
\hline Alone & 13.51 & & Ref. \\
\hline With spouse & 8.56 & & $0.785(0.570-1.082)$ \\
\hline Others & 8.32 & & $0.718^{* *}(0.548-0.939)$ \\
\hline Working status & & * & \\
\hline Never/Not working & 9.17 & & Ref. \\
\hline Currently working & 7.87 & & $1.190 * *(1.007-1.406)$ \\
\hline Retired & 7.74 & & $1.302^{*}(0.954-1.776)$ \\
\hline Self-rated health & & * & \\
\hline Good & 6.19 & & Ref. \\
\hline Poor & 16.42 & & $2.586^{* * *}(2.237-2.989)$ \\
\hline ADL difficulty & & * & \\
\hline No & 6.69 & & Ref. \\
\hline Yes & 15.34 & & $1.736^{* * *}(1.451-2.077)$ \\
\hline IADL difficulty & & * & \\
\hline No & 5.58 & & Ref. \\
\hline Yes & 12.06 & & $1.694 * *(1.429-2.007)$ \\
\hline MPCE quintile & & * & \\
\hline Poorest & 8.88 & & Ref. \\
\hline Poorer & 7.92 & & $0.916(0.759-1.105)$ \\
\hline Middle & 8.17 & & $1.035(0.825-1.298)$ \\
\hline Richer & 8.74 & & $1.111(0.900-1.371)$ \\
\hline Richest & 9.92 & & $1.337^{* * *}(1.088-1.642)$ \\
\hline Religion & & * & \\
\hline Hindu & 8.6 & & Ref. \\
\hline Muslim & 9.63 & & $1.049(0.843-1.305)$ \\
\hline Others & 7.94 & & $0.93(0.53,1.64)$ \\
\hline Caste & & * & \\
\hline SC/ST & 8.48 & & Ref. \\
\hline $\mathrm{OBC}$ & 9.25 & & $1.282^{* * *}(1.080-1.520)$ \\
\hline
\end{tabular}


Table 2 Bivariate and logistic regression estimates for major depression among older adults in India (Continued)

\begin{tabular}{|c|c|c|c|}
\hline Variables & $\%$ & $p<0.05$ & AOR $(95 \% \mathrm{Cl})$ \\
\hline Others & 7.9 & & $1.056(0.873-1.278)$ \\
\hline Place of residence & & * & \\
\hline Rural & 9.62 & & Ref. \\
\hline Urban & 6.34 & & $0.826^{* *}(0.698-0.978)$ \\
\hline Region & & * & \\
\hline North & 6.8 & & Ref. \\
\hline Central & 14.53 & & $2.275^{* * *}(1.840-2.813)$ \\
\hline East & 8.28 & & $1.052(0.864-1.281)$ \\
\hline Northeast & 5.63 & & $0.813(0.600-1.101)$ \\
\hline West & 5.82 & & $0.599^{* * *}(0.474-0.758)$ \\
\hline South & 7.69 & & $1.078(0.856-1.358)$ \\
\hline Total & 8.67 & & \\
\hline
\end{tabular}

more likely to suffer from cognitive impairment [OR: 1.22, CI: $1.02-1.48]$ in reference to the older adults who were not depressed. Also, the older population of rural areas was significantly more likely to be cognitively impaired [OR: 2.12, CI: 1.73-2.06] than their urban counterparts. In comparison to the population in the age group of 60-69, elderly aged 80 and above were nearly three times more likely to suffer from cognitive impairments [OR: 2.92, CI: 2.40-3.56]. Importantly, females were 2.3 times more likely to develop cognitive impairment [OR: 2.26, CI: 1.95-2.63] as compared to men. The odds of cognitive impairment were significantly higher among the older adults who were living with their spouse in comparison to the older adults who were living alone [OR: 1.61, CI: 1.19-2.16]. The older adults who were economically active or retired were $23 \%$ [OR: 0.77, CI: 0.66-0.90] and $47 \%$ [OR: 0.53, CI: 0.33-0.83] respectively less likely to develop cognitive impairment in comparison to the older adults who were economically inactive. Further, the odds of cognitive impairment were lower among older adults who were physically active [OR: 0.74, CI: 0.54-1.02] and had community involvement [OR: $0.60, \mathrm{CI}: 0.43-0.84$ ] as compared to their reference categories. According to the results, the odds of cognitive impairment decreased with the increase in educational level and MPCE quintile.

Model-2 represents the interaction effect of major depression along with the place of residence of older individuals on cognitive impairment. Older adults who were depressed and belonged to rural areas were 2.58 times [AOR: 2.58 , CI: $1.95-3.41]$ significantly more likely to be cognitively impaired than those who were not depressed and resided in urban areas.

\section{Discussion}

The current analysis of the cross-sectional study shows that the prevalence estimate of LLD in a representative sample of older adults aged 60 and above in India is $8.7 \%$. The bivariate analysis shows no significance in the prevalence of LLD with an increasing age. This is in variance with the earlier findings that increasing age is associated with more neurological or chronic

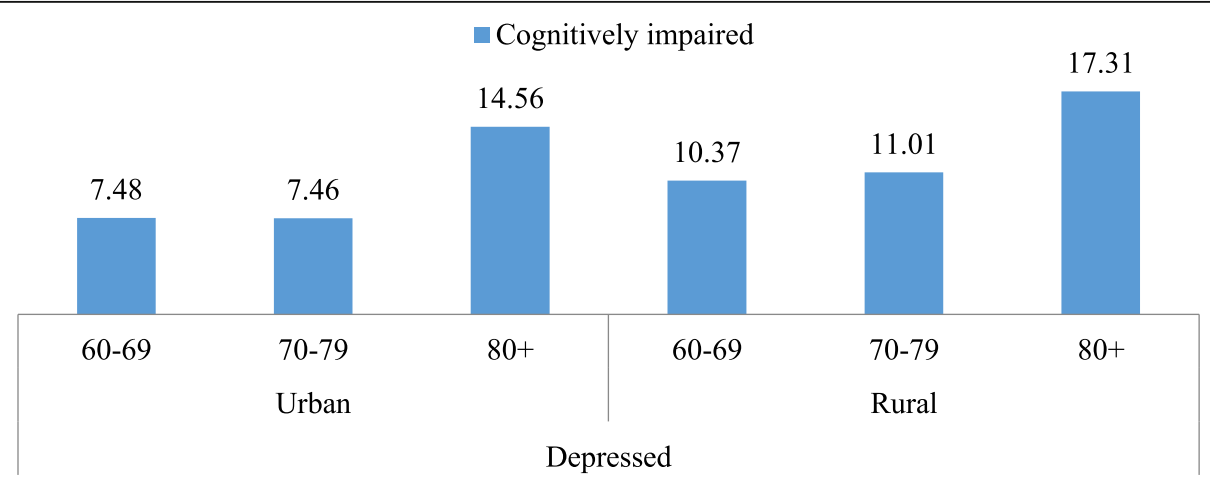

Fig. 1 Percentage of older adults who are depressed and cognitively impaired by age and place of residence 


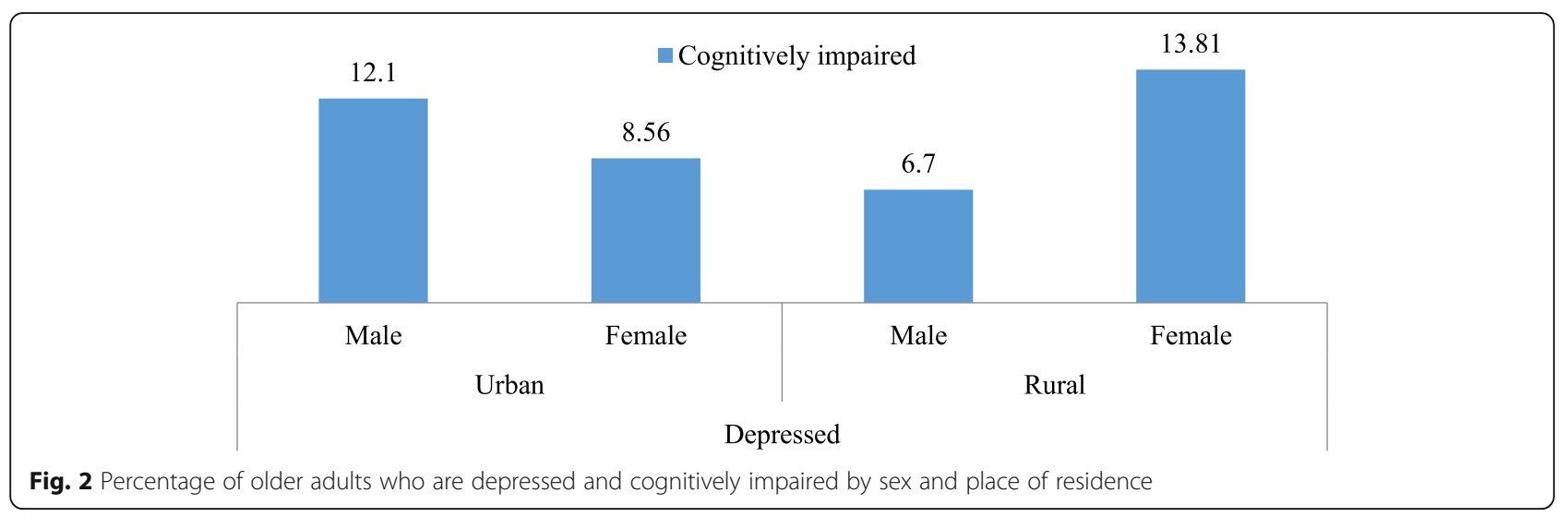

degenerative disorders [41]. However, on contrary, the multivariate results show a negative association of LLD with increasing age. In accordance with earlier studies, the results indicate that older adults who are currently not in union and living alone are more likely to suffer from depression [42-44]. Also, as evidence suggests, solo living and widowhood may create a situation of loneliness, isolation, and loss of roles that can lead to depression [45-47].

With regard to work status, retirement is significantly associated with LLD. This is in line with the studies from Ethiopia, Sudan, and Korea [48-50]. This could be explained as the retired person may not have adequate opportunity to interact with other people to share their ideas and feelings. This brings a sense of loss, leaving a person feeling isolated and struggling to understand what their value is and such feelings might contribute to the development of depressive symptoms in their older ages [51]. In concordance with previous studies [52-54], the current study also showed that older individuals with poor self-rated health and low functional ability in ADL and IADL are at higher risk of suffering from LLD. It is also evident from the study that individuals living in rural areas are more likely to suffer from depression in later years of life. This result is consistent with the findings from a study conducted in China showing a higher proportion of depressive symptomatology and feelings of loneliness among rural resident older adults [55].

Studies in various developed and developing countries have proven that there is a higher prevalence of cognitive impairment in low-and middle-income countries [56-58]. Further, various evidence in India has also shown an upward trend in the prevalence of cognitive impairment since the 1990s $[59,60]$. In this study, the overall prevalence of cognitive impairment among the older population is found to be substantially high with $13.7 \%$. Studies conducted in different parts of the country also have documented nearly similar prevalence $[59,61]$.
Several studies have shown that the risk of cognitive impairment increases with age $[2,62]$. In this study, cognitive impairment is significantly higher among older adults aged 70 and above compared to those in the age group of 60-69 years and highest in the 80 plus population. Aging is associated with various changes in brain structure and function [63, 64]. More so, the brain volume starts shrinking after the age of 40 , and the rate increases after the age of 70 which leads to a decline in executive functioning resulting in cognitive impairment [65]. The analysis revealed that females are significantly more likely to develop cognitive impairment than males, which corresponds to the study by Khanna \& Metgud in 2020 [66]. A possible explanation for the high prevalence of cognitive impairment among older women could be the loss of estrogen hormone after menopause. Some researchers have reported that declines in estrogen level could lead to deficits in the cognitive ability of postmenopausal women $[67,68]$. Further, according to this study, the risk of cognitive impairment is substantially higher among older adults living in rural areas as compared to their counterparts in urban areas and is similar to the findings in earlier studies $[38,69,70]$.

Older adults who are currently in a marital union or living with their spouses are found to be at greater risk of cognitive impairment. However, this has not been reported in other studies [38, 62] and needs further investigation. Besides, education and socioeconomic status have a strong negative association with cognitive impairment and the results are parallel to a study conducted in India [71], supporting the brain reserve hypothesis that more years of education translates into greater cognitive reserve $[70,72,73]$. Further, high socio-economic status means greater access to healthcare services, high nutritious food intake as well as higher levels of social activities, which have been proven to improve cognitive functioning [74, 75]. A study conducted in Beijing has documented that less social interaction is an independent risk factor for cognitive impairment [76]. Similarly, 
Table 3 Bivariate and logistic regression estimates for cognitive impairment by background characteristics among older adults in India

\begin{tabular}{|c|c|c|c|c|}
\hline Variables & $\%$ & $p<0.05$ & $\begin{array}{l}\text { AOR }(95 \% \mathrm{Cl}) \\
\text { Model } 1\end{array}$ & $\begin{array}{l}\text { AOR }(95 \% \mathrm{Cl}) \\
\text { Model } 2\end{array}$ \\
\hline Depression & & $*$ & & \\
\hline No & 13.23 & & Ref. & \\
\hline Yes & 18.26 & & $1.224^{* *}(1.015-1.476)$ & \\
\hline Place of residence & & $*$ & & \\
\hline Urban & 6.69 & & Ref. & \\
\hline Rural & 16.67 & & $2.120^{* * *}(1.732-2.595)$ & \\
\hline Age (in years) & & $*$ & & \\
\hline Young old (60-69) & 10.03 & & Ref. & Ref. \\
\hline Old old (70-79) & 16.77 & & $1.635^{* * *}(1.395-1.916)$ & $1.634^{* * *}(1.395-1.915)$ \\
\hline Oldest old (80+) & 27.76 & & $2.922^{* * *}(2.396-3.564)$ & $2.921^{* * *}(2.396-3.562)$ \\
\hline Sex & & $*$ & & \\
\hline Male & 7.14 & & Ref. & Ref. \\
\hline Female & 20.03 & & $2.264^{* * *}(1.947-2.634)$ & $2.266^{* * *}(1.948-2.636)$ \\
\hline Marital status & & * & & \\
\hline Currently in union & 9.68 & & Ref. & Ref. \\
\hline Not in union & 20.77 & & $1.536^{* * *}(1.307-1.806)$ & $1.536^{* * *}(1.306-1.805)$ \\
\hline Living arrangement & & $*$ & & \\
\hline Alone & 19.07 & & Ref. & Ref. \\
\hline With spouse & 11.92 & & $1.605^{* * *}(1.191-2.163)$ & $1.604^{* * *}(1.190-2.162)$ \\
\hline Others & 13.73 & & $1.174(0.927-1.487)$ & $1.174(0.927-1.487)$ \\
\hline Working status & & $*$ & & \\
\hline Never/Not working & 17.08 & & Ref. & Ref. \\
\hline Currently working & 9.98 & & $0.773^{* * *}(0.662-0.903)$ & $0.773^{* * *}(0.662-0.903)$ \\
\hline Retired & 2.24 & & $0.526^{* * *}(0.333-0.833)$ & $0.527^{* * *}(0.333-0.833)$ \\
\hline \multicolumn{5}{|l|}{ Community involvement } \\
\hline No & 14.12 & * & Ref. & Ref. \\
\hline Yes & 5.24 & & $0.604^{* * *}(0.433-0.842)$ & $0.603^{* * *}(0.432-0.842)$ \\
\hline \multicolumn{5}{|l|}{ Physical activity } \\
\hline No & 14.87 & * & Ref. & Ref. \\
\hline Yes & 6.85 & & $0.741^{*}(0.536-1.025)$ & $0.740^{*}(0.535-1.025)$ \\
\hline Educational status & & * & & \\
\hline No/primary education & 18.79 & & Ref. & Ref. \\
\hline Secondary & 1.05 & & $0.0879 * * *(0.0600-0.129)$ & $0.0881^{* * *}(0.0601-0.129)$ \\
\hline Higher & 0.42 & & $0.0616^{* * *}(0.0254-0.149)$ & $0.0616^{* * *}(0.0254-0.149)$ \\
\hline MPCE quintile & & * & & \\
\hline Poorest & 18.55 & & Ref. & Ref. \\
\hline Poorer & 15.75 & & $0.905(0.757-1.082)$ & $0.906(0.758-1.082)$ \\
\hline Middle & 12.46 & & $0.716^{* * *}(0.600-0.853)$ & $0.716^{* * *}(0.601-0.854)$ \\
\hline Richer & 10.88 & & $0.645^{* * *}(0.530-0.785)$ & $0.645^{* * *}(0.530-0.786)$ \\
\hline Richest & 9.81 & & $0.678^{* * *}(0.513-0.896)$ & $0.679^{* * *}(0.514-0.897)$ \\
\hline Religion & & * & & \\
\hline Hindu & 13.37 & & Ref. & Ref. \\
\hline
\end{tabular}


Table 3 Bivariate and logistic regression estimates for cognitive impairment by background characteristics among older adults in India (Continued)

\begin{tabular}{|c|c|c|c|c|}
\hline \multirow[t]{2}{*}{ Variables } & \multirow[t]{2}{*}{$\%$} & \multirow[t]{2}{*}{$p<0.05$} & \multirow{2}{*}{$\begin{array}{l}\text { AOR }(95 \% \mathrm{Cl}) \\
\text { Model } 1\end{array}$} & \multirow{2}{*}{$\begin{array}{l}\text { AOR }(95 \% \mathrm{Cl}) \\
\text { Model } 2\end{array}$} \\
\hline & & & & \\
\hline Muslim & 14.62 & & $1.261 *(1.007-1.579)$ & $0.892(0.714-1.113)$ \\
\hline Others & 15.72 & & $1.121(0.898-1.399)$ & $1.127(0.837-1.515)$ \\
\hline Caste & & * & & \\
\hline $\mathrm{SC} / \mathrm{ST}$ & 19.74 & & Ref. & Ref. \\
\hline $\mathrm{OBC}$ & 12.03 & & $0.643^{* * *}(0.554-0.747)$ & $1.464^{* *}(1.230-1.742)$ \\
\hline Others & 10.8 & & $0.683^{* * *}(0.574-0.813)$ & $0.941(0.789-1.123)$ \\
\hline Region & & * & & \\
\hline North & 13.02 & & Ref. & Ref. \\
\hline Central & 14.27 & & $1.007(0.823-1.234)$ & $1.009(0.824-1.235)$ \\
\hline East & 14.78 & & $1.099(0.906-1.333)$ & $1.100(0.907-1.334)$ \\
\hline Northeast & 15.35 & & $1.317^{* *}(1.061-1.635)$ & $1.317^{* *}(1.061-1.635)$ \\
\hline West & 10.97 & & $0.974(0.781-1.213)$ & $0.975(0.782-1.214)$ \\
\hline South & 15.02 & & $1.541^{* * *}(1.256-1.892)$ & $1.542^{* * *}(1.257-1.893)$ \\
\hline \multicolumn{5}{|c|}{ Depression \# Place of residence } \\
\hline No \# Urban & & & & Ref. \\
\hline Yes \# Urban & & & & $1.390(0.818-2.362)$ \\
\hline No \# Rural & & & & $2.148^{* * *}(1.729-2.668)$ \\
\hline Yes \# Rural & & & & $2.579^{* * *}(1.951-3.409)$ \\
\hline Total & 13.66 & & & \\
\hline
\end{tabular}

$\%:$ Percentage; Ref: Reference category; ${ }^{\text {if }} p<0.05,{ }^{*}$ if $p<0.01$, ${ }^{* * *}$ if $p<0.001 ; A O R$ Odds Ratio Adjusted for all covariates; MPCE Monthly per capita consumption expenditure

according to our study, the prevalence of cognitive impairment was higher among older individuals with no community involvement.

Moreover, the study's results back up the theory that LLD can be a risk factor for the development of cognitive disability in older people. According to a hypothesis, late-life depressive symptoms could indicate an underlying neuropathologic disorder that contributes to cognitive deterioration over time [77, 78]. Depressive symptoms have also been linked to cognitive impairment, according to many studies [6, 42, 79]. Mild depression, on the other hand, does not result in significant cognitive dysfunction, whereas persistent depression in its most extreme form does [80]. Several pieces of literature have suggested that LLD sufferers have more cognitive deficits than those suffering from earlyonset depression [24, 81]. Depression-related executivetype cognitive impairments can explain why depressed persons are more disabled [82]. Although geriatric depression may increase the risk of cognitive impairments, studies have also demonstrated co-occurrence of depression, cognitive functioning, and dementia [78, 83], and possible reverse causation between them $[84,85]$.
Similarly, the prevalence of depression in dementia has been reported to range between 9 and $68 \%$ [86], indicating the need for further investigation of the observed pathways. Further, in our study, an important association between depression and rural residence on cognitive impairment is observed in the regression model with interaction analysis. The older adults suffering from LLD and living in rural areas exhibit greater cognitive deficits than those living in urban areas. The result is in line with various studies that suggested that elderly living in urban areas have lower dementia rates and do better on cognitive tests $[82,87]$. Though the association is not well understood, some theories explain the disparity by pointing to rural dwellers' lower educational quality and reduced access to public and health services [87].

The current study has major limitations to be acknowledged. Importantly, the study was cross-sectional; therefore, any causal pathways cannot be definitively determined from the results, rather reverse causation stands as a possibility in many of the cases including depression and cognitive impairment. The forthcoming followed-up wave 2 of the LASI data will provide greater scope to understand the causal relationship between 
depressive symptoms and cognitive impairments among older Indian adults. Also, the findings can be somewhat biased towards a cognitively well-functioning population due to a substantially higher illiteracy rate and the unavailability of information on institutionalized older people and exclusion of proxy-assisted respondents, and a small portion of cognitive data that was missing in the analyses. Hence, it suggests that the present results may not generalize to individuals with severely impaired cognitive status, as they were not adequately sampled in this study. However, this study has several strengths too. First, the data were derived from a large, national probability sample of older people aged 60 and above, enhancing external validity and generalizability of the current findings. Again, the measure of cognition was comprehensive and multi-faceted, and it tapped into participants' memory capabilities as well as their mental status.

\section{Conclusions}

Because of the strong association between the two, cognitive impairment and LLD have become major health concerns among older adults. Since life expectancy is growing, older age is one of the most important nonmodifiable risk factors for cognitive impairment and should be included in health interventions. Furthermore, depression is linked to an increased risk of cognitive decline and dementia; therefore, failing to diagnose and treat LLD in later life may have significant health implications. Moreover, treatment under the care of a cognitive neurologist or geriatric psychiatrist is recommended for people with LLD and cognitive disability due to both the disorders' complex existence.

\section{Abbreviations}

LLD: Late-life depression.; AOR: Adjusted Odds Ratio.; Cl: Confidence Interval.; MPCE: Monthly per capita consumption expenditure.; ADL: Activities of daily living.; IADL: Instrumental activities of daily living.

\section{Supplementary Information}

The online version contains supplementary material available at https://doi. org/10.1186/s12877-021-02314-7.

\section{Additional file 1.}

\section{Acknowledgements}

Not applicable.

\section{Data sharing statement}

The study uses a secondary data which is available on reasonable request through https://www.iipsindia.ac.in/content/lasi-wave-i.

\section{Consent to participate}

Not applicable.

\section{Authors' contributions}

T. Muhammad contributed to the conceptualization and the study design and acquisition of the study data. T. Muhammad analyzed the study data. T. Muhammad and Trupti Meher contributed to extensive literature review and writing of the manuscript. Both the authors contributed to finalising the manuscript, subsequent revisions, and approved submission.

Funding

No funding was received for the study.

\section{Declarations}

Ethics approval and consent to participate

Not applicable.

\section{Consent for publication}

Not applicable.

\section{Competing interests}

The authors declare that there is no competing interest.

Received: 3 April 2021 Accepted: 2 June 2021

Published online: 15 June 2021

\section{References}

1. Perna L, Wahl HW, Mons U, et al. Cognitive impairment, all-cause and cause-specific mortality among non-demented older adults. Age Ageing. Epub ahead of print 2015. DOl: https://doi.org/10.1093/ageing/afu188.

2. Sherina MS, Rampal L, Mustaqim A. Cognitive impairment among the elderly in a rural community in Malaysia. Med J Malaysia.

3. Prince M, Wimo A, Guerchet M, et al. World Alzheimer Report 2015: The Global Impact of Dementia - An analysis of prevalence, incidence, cost and trends. Alzheimer's Dis Int. Epub ahead of print 2015. DOl: https://doi.org/1 0.1111/j.0963-7214.2004.00293.x.

4. Prince $M$, Bryce $R$, Albanese $E$, et al. The global prevalence of dementia: A systematic review and metaanalysis. Alzheimer's Dement 2013; 9: 63-75.e2.

5. Blazer DG. Depression in late life: Review and commentary. Journals of Gerontology - Series A Biological Sciences and Medical Sciences. Epub ahead of print 2003. DOl: https://doi.org/10.1093/gerona/58.3.m249.

6. Koenig AM, Bhalla RK, Butters MA. Cognitive functioning and late-life depression. Journal of the International Neuropsychological Society. Epub ahead of print 2014. DOl: https://doi.org/10.1017/S1355617714000198.

7. Beekman ATF, Penninx BWJH, Deeg DJH, et al. The impact of depression on the well-being, disability and use of services in older adults: A longitudinal perspective. Acta Psychiatr Scand. Epub ahead of print 2002. DOI: https://doi. org/10.1034/j.1600-0447.2002.10078.x.

8. Steffens DC, Otey E, Alexopoulos GS, et al. Perspectives on depression, mild cognitive impairment, and cognitive decline. Archives of General Psychiatry. Epub ahead of print 2006. DOI: https://doi.org/10.1001/archpsyc.63.2.130.

9. Berkman LF, Berkman CS, Kasl S, et al. Depressive symptoms in relation to physical health and functioning in the elderly. Am J Epidemiol. Epub ahead of print 1986. DOl: https://doi.org/10.1093/oxfordjournals.aje.a114408.

10. Doraiswamy PM, Khan ZM, Donahue RMJ, et al. The spectrum of quality-oflife impairments in recurrent geriatric depression. Journals Gerontol - Ser A Biol Sci Med Sci. Epub ahead of print 2002. DOl: https://doi.org/10.1093/ gerona/57.2.M134

11. Steffens DC, Fisher GG, Langa KM, et al. Prevalence of depression among older Americans: The aging, demographics and memory study. Int Psychogeriatrics. Epub ahead of print 2009. DOI: https://doi.org/10.1017/S1 041610209990044

12. Waraich P, Goldner EM, Somers JM, et al. Prevalence and Incidence Studies of Mood Disorders: A Systematic Review of the Literature. Canadian Journal of Psychiatry. Epub ahead of print 2004. DOI: https://doi.org/10.1177/ 070674370404900208.

13. Blazer DG. Psychiatry and the oldest old. American Journal of Psychiatry. Epub ahead of print 2000. DOI: https://doi.org/10.1176/appi.ajp.157.12.1915.

14. Reynolds CF, Alexopoulos GS, Katz IR, et al. Chronic depression in the elderly: Approaches for prevention. Drugs and Aging. Epub ahead of print 2001. DOl: https://doi.org/10.2165/00002512-200118070-00004.

15. Schweitzer I, Tuckwell V, O'Brien J, et al. Is late onset depression a prodrome to dementia? International Journal of Geriatric Psychiatry. Epub ahead of print 2002. DOl: https://doi.org/10.1002/gps.525.

16. Bruce ML, Ten Have TR, Reynolds CF, et al. Reducing Suicidal Ideation and Depressive Symptoms in Depressed Older Primary Care Patients: A 
Randomized Controlled Trial. J Am Med Assoc. Epub ahead of print 2004. DOl: https://doi.org/10.1001/jama.291.9.1081.

17. Sheline YI, Barch DM, Garcia K, et al. Cognitive Function in Late Life Depression: Relationships to Depression Severity, Cerebrovascular Risk Factors and Processing Speed. Biol Psychiatry. Epub ahead of print 2006. DOl: https://doi.org/10.1016/j.biopsych.2005.09.019.

18. Arve S, Tilvis RS, Lehtonen A, et al. Coexistence of lowered mood and cognitive impairment of elderly people in five birth cohorts. Aging Clin Exp Res. Epub ahead of print 1999. DOl: https://doi.org/10.1007/bf03399646.

19. Kingston $A$, Robinson $L$, Booth $H$, et al. Projections of multi-morbidity in the older population in England to 2035: Estimates from the Population Ageing and Care Simulation (PACSim) model. Age Ageing. Epub ahead of print 2018. DOl: https://doi.org/10.1093/ageing/afx201.

20. Cianciarullo Minett TSC, Da Silva RV, Ortiz KZ, et al. Subjective memory complaints in an elderly sample: A cross-sectional study. Int J Geriatr Psychiatry. Epub ahead of print 2008. DOl: https://doi.org/10.1002/gps.1836.

21. Steffens DC. Separating mood disturbance from mild cognitive impairment in geriatric depression. International Review of Psychiatry. Epub ahead of print 2008. DOl: https://doi.org/10.1080/09540260802094589.

22. Steffens DC, Potter GG. Geriatric depression and cognitive impairment. Psychological Medicine. Epub ahead of print 2008. DOl: https://doi.org/10.1 017/S003329170700102X.

23. Nebes RD, Butters MA, Mulsant BH, et al. Decreased working memory and processing speed mediate cognitive impairment in geriatric depression. Psychol Med. Epub ahead of print 2000. DOl: https://doi.org/10.1017/S0033291799001968.

24. Butters MA, Whyte EM, Nebes RD, et al. The nature and determinants of neuropsychological functioning in late-life depression. Arch Gen Psychiatry. Epub ahead of print 2004. DOI: https://doi.org/10.1001/archpsyc.61.6.587.

25. Bhalla RK, Butters MA, Mulsant BH, et al. Persistence of neuropsychologic deficits in the remitted state of late-life depression. Am J Geriatr Psychiatry. Epub ahead of print 2006. DOl: https://doi.org/10.1097/01.JGP.0000203130.45421.69.

26. Barnes DE, Alexopoulos GS, Lopez OL, et al. Depressive symptoms, vascular disease, and mild cognitive impairment: Findings from the cardiovascular health study. Arch Gen Psychiatry. Epub ahead of print 2006. DOI: https:// doi.org/10.1001/archpsyc.63.3.273.

27. Jorm AF. History of depression as a risk factor for dementia: An updated review. Aust N Z J Psychiatry. Epub ahead of print 2001. DOI: https://doi. org/10.1046/j.1440-1614.2001.00967.x.

28. Diniz BS, Butters MA, Albert SM, et al. Late-life depression and risk of vascular dementia and Alzheimer's disease: Systematic review and metaanalysis of community-based cohort studies. British Journal of Psychiatry. Epub ahead of print 2013. DOl: https://doi.org/10.1192/bjp.bp.112.118307.

29. Perini G, Ramusino MC, Sinforiani E, et al. Cognitive impairment in depression: Recent advances and novel treatments. Neuropsychiatr Dis Treat 2019; 15: 1249-1258.

30. International Institute for Population Sciences (IIPS), NPHCE, MoHFW HTHCS of PH (HSPH) and the $\mathrm{U}$ of SC (USC). Longitudinal Ageing Study in India (LASI) Wave 1, 2017-18, India Report. Mumbai., 2020.

31. Trainor K, Mallett J, Rushe T. Age related differences in mental health scale scores and depression diagnosis: Adult responses to the CIDI-SF and MHI-5. J Affect Disord 2013; 151: 639-645.

32. Muhammad T, Srivastava S, Sekher TV. Association of self-perceived income sufficiency with cognitive impairment among older adults: a populationbased study in India. BMC Psychiatry. 2021;21(1). https://doi.org/10.1186/s12 888-021-03257-4.

33. Muhammad T, Srivastava S. Why Rotational Living Is Bad for Older Adults ? Evidence from a Cross- Sectional Study in India. J Popul Ageing; 1. Epub ahead of print 2020. DOI: https://doi.org/10.1007/s12062-020-09312-4.

34. Srivastava S, Chauhan S, Muhammad T, et al. Older adults ' psychological and subjective well-being as a function of household decision making role: Evidence from cross-sectional survey. Clin Epidemiol Glob Heal 2021; 10: 100676.

35. Srivastava S, Joseph VKJ, Dristhi D, et al. Interaction of physical activity on the association of obesity-related measures with multimorbidity among older adults: a population-based cross-sectional study in India. BMJ Open. 2021;11(5). https://doi.org/10.1136/bmjopen-2021-050245.

36. Osborne J, King JE. Binary Logistic Regression. In: Best Practices in Quantitative Methods. SAGE Publications, Inc., 2011, pp. 358-384.

37. Chauhan S, Srivastava S, Kumar P, et al. Interaction of substance use with physical activity and its effect on depressive symptoms among adolescents. J Subst Use 2020; 1-7.
38. Muhammad T, Govindu M, Srivastava S. Relationship between chewing tobacco, smoking, consuming alcohol and cognitive impairment among older adults in India: a cross-sectional study. BMC Geriatr 2021; 21: 85.

39. Srivastava S, Muhammad T. Violence and associated health outcomes among older adults in India: A gendered perspective. SSM - Popul Heal; 12. Epub ahead of print 1 December 2020. DOl: https://doi.org/10.1016/j. ssmph.2020.100702.

40. StataCorp. Stata: Release 14. Statistical Software. 2015.

41. Niti M, Ng TP, Kua EH, et al. Depression and chronic medical illnesses in asian older adults: The role of subjective health and functional status. Int J Geriatr Psychiatry. Epub ahead of print 2007. DOl: https://doi.org/10.1002/gps.1789.

42. Ortiz GG, Arias-Merino ED, Flores-Saiffe ME, et al. Prevalence of cognitive impairment and depression among a population aged over 60 years in the Metropolitan Area of Guadalajara, Mexico. Curr Gerontol Geriatr Res. Epub ahead of print 2012. DOI: https://doi.org/10.1155/2012/175019.

43. Sahni B, Bala K, Kumar T, et al. Prevalence and determinants of geriatric depression in North India: A cross-sectional study. J Fam Med Prim Care Epub ahead of print 2020. DOI: https://doi.org/10.4103/ffmpc.jfmpc_357_20.

44. Taqui AM, Itrat A, Qidwai W, et al. Depression in the elderly: Does family system play a role? A cross-sectional study. BMC Psychiatry 2007; 7: 57.

45. Nakagomi A, Koichiro S, Hanazato M, et al. Does community-level social capital mitigate the impact of widowhood \& living alone on depressive symptoms?: A prospective, multi-level study. Soc Sci Med 2020; 259: 113140.

46. Jadhav A, Weir D. Widowhood and Depression in a Cross-National Perspective: Evidence from the United States, Europe, Korea, and China. Journals Gerontol - Ser B Psychol Sci Soc Sci 2018; 73: e143-e153.

47. Lin $\mathrm{PC}$, Wang HH. Factors associated with depressive symptoms among older adults living alone: An analysis of sex difference. Aging Ment Heal 2011; 15: 1038-1044.

48. Park H, Kang MY. Effects of voluntary/involuntary retirement on their own and spouses' depressive symptoms. Compr Psychiatry. Epub ahead of print 2016. DOl: https://doi.org/10.1016/j.comppsych.2015.11.009.

49. Mirkena Y, Reta MM, Haile K, et al. Prevalence of depression and associated factors among older adults at ambo town, Oromia region, Ethiopia. BMC Psychiatry. Epub ahead of print 2018. DOl: https://doi.org/10.1186/s12888-01 8-1911-8.

50. Assil SM, Zeidan ZA. Prevalence of depression and associated factors among elderly Sudanese: A household survey in Khartoum State. East Mediterr Heal J. Epub ahead of print 2013. DOl: https://doi.org/10.26719/2013.19.5.435.

51. Fernández-Niño JA, Bonilla-Tinoco LJ, Manrique-Espinoza BS, et al. Work status, retirement, and depression in older adults: An analysis of six countries based on the Study on Global Ageing and Adult Health (SAGE). SSM - Popul Heal 2018; 6: 1-8.

52. Chang M, Phillips C, Coppin AK, et al. An association between incident disability and depressive symptoms over 3 years of follow-up among older women: The Women's Health and Aging Study. Aging Clin Exp Res. Epub ahead of print 2009. DOI: https://doi.org/10.1007/BF03325228.

53. Yang Y. How does functional disability affect depressive symptoms in late life? The role of perceived social support and psychological resources. J Health Soc Behav. Epub ahead of print 2006. DOl: https:/doi.org/10.1177/ 002214650604700404.

54. Noh JW, Kwon YD, Park J, et al. Relationship between physical disability and depression by gender: A panel regression model. PLoS One. Epub ahead of print 2016. DOl: https://doi.org/10.1371/journal.pone.0166238.

55. Dong $X Q$, Simon MA. Health and aging in a Chinese population: Urban and rural disparities. Geriatr Gerontol Int 2010; 10: 85-93.

56. Miu J, Negin J, Salinas-Rodriguez A, et al. Factors associated with cognitive function in older adults in Mexico. Glob Health Action; 9. Epub ahead of print 2016. DOI: https://doi.org/10.3402/gha.v9.30747.

57. Langa $\mathrm{K}$, Larson $\mathrm{E}$, Crimmins $\mathrm{E}$, et al. A comparison of the prevalence of dementia in the United States in 2000 and 2012. JAMA Intern Med 2017; 177: 51-8.

58. Vancampfort D, Stubbs B, Firth J, et al. Associations between handgrip strength and mild cognitive impairment in middle-aged and older adults in six lowand middle-income countries. Int J Geriatr Psychiatry 2019; 34: 609-616.

59. Shaji S, Promodu K, Abraham T, et al. An epidemiological study of dementia in a rural community in Kerala, India. Br J Psychiatry. Epub ahead of print 1996. DOl: https://doi.org/10.1192/bjp.168.6.745.

60. Mohan D, lype T, Varghese $\mathrm{S}$, et al. A cross-sectional study to assess prevalence and factors associated with mild cognitive impairment among older adults in an urban area of Kerala, South India. BMJ Open; 9. Epub ahead of print 2019. DOI: https://doi.org/10.1136/bmjopen-2018-025473. 
61. Tripathi RK, Tiwari SC. Cognitive dysfunction in normally aging urban older adults: A community-based study. Indian J Psychol Med. Epub ahead of print 2011. DOI: https://doi.org/10.4103/0253-7176.92059.

62. Saw YM, Saw TN, Than TM, et al. Cognitive impairment and its risk factors among Myanmar elderly using the Revised Hasegawa's Dementia Scale: A cross-sectional study in Nay Pyi Taw, Myanmar. PLoS One. Epub ahead of print 2020. DOl: https://doi.org/10.1371/journal.pone.0236656.

63. Deary IJ, Corley J, Gow AJ, et al. Age-associated cognitive decline. British Medical Bulletin. Epub ahead of print 2009. DOl: https://doi.org/10.1093/ bmb/ldp033.

64. Holmes AJ, Hollinshead MO, Roffman JL, et al. Individual differences in cognitive control circuit anatomy link sensation seeking, impulsivity, and substance use. J Neurosci 2016; 36: 4038-4049.

65. Peters R. Ageing and the brain. Postgrad Med J 2006; 82: 84-88.

66. Khanna A, Metgud C. Prevalence of cognitive impairment in elderly population residing in an urban area of Belagavi. J Fam Med Prim Care. Epub ahead of print 2020. DOl: https://doi.org/10.4103/jfmpc.jfmpc_240_20.

67. Henderson WW. Cognitive changes after menopause: Influence of estrogen. Clin Obstet Gynecol. Epub ahead of print 2008. DOl: https://doi.org/10.1097/ GRF.0b013e318180ba10.

68. Sliwinski JR, Johnson AK, Elkins GR. Memory decline in peri- and postmenopausal women: The potential of mind-body medicine to improve cognitive performance. Integr Med Insights. Epub ahead of print 2014. DOI: https://doi.org/10.4137//MI.S15682.

69. Zhang $Y, X u Y, N i e ~ H$, et al. Prevalence of dementia and major dementia subtypes in the Chinese populations: A meta-analysis of dementia prevalence surveys, 1980-2010. J Clin Neurosci 2012; 19: 1333-1337.

70. Sharma D, Mazta S, Parashar A. Prevalence of cognitive impairment and related factors among elderly: A population-based study. J Dr NTR Univ Heal Sci 2013; 2: 171

71. Patel $R$, Singh U. Prevalence study of cognitive impairment and its associated sociodemographic variables using mini-mental status examination among elderly population residing in field practice areas of a medical college. Indian J Community Med. Epub ahead of print 2018. DOI: https://doi.org/10.4103/ijcm.IJCM_102_17.

72. Håkansson K, Rovio S, Helkala EL, et al. Association between mid-life marital status and cognitive function in later life: Population based cohort study. BMJ. Epub ahead of print 2009. DOI: https://doi.org/10.1136/bmj.b2462.

73. Foubert-Samier A, Catheline G, Amieva H, et al. Education, occupation, leisure activities, and brain reserve: A population-based study. Neurobiol Aging 2012; 33: 423.e15-423.e25.

74. Middleton LE, Yaffe K. Promising strategies for the prevention of dementia. Archives of Neurology. Epub ahead of print 2009. DOl: https://doi.org/10.1 001/archneurol.2009.201.

75. Rosso AL, Flatt JD, Carlson MC, et al. Neighborhood socioeconomic status and cognitive function in late life. Am J Epidemiol. Epub ahead of print 2016. DOI: https://doi.org/10.1093/aje/kwv337.

76. Han R, Tang Z, Ma L. Related factors of cognitive impairment in communitydwelling older adults in Beijing Longitudinal Study of Aging. Aging Clin Exp Res. Epub ahead of print 2019. DOl: https://doi.org/10.1007/s40520-018-0943-8.

77. Butters MA, Young JB, Lopez $\mathrm{O}$, et al. Pathways linking late-life depression to persistent cognitive impairment and dementia. Dialogues Clin Neurosci. Epub ahead of print 2008. DOI: https://doi.org/10.31887/dcns.2008.10.3/mabutters.

78. Panza F, Frisardi V, Capurso C, et al. Late-Life depression, mild cognitive impairment, and dementia: Possible continuum? Am J Geriatr Psychiatry. Epub ahead of print 2010. DOI: https://doi.org/10.1097/JGP. Ob013e3181b0fa13.

79. Rosenberg PB, Mielke MM, Xue QL, et al. Depressive symptoms predict incident cognitive impairment in cognitive healthy older women. Am J Geriatr Psychiatry. Epub ahead of print 2010. DOI: https://doi.org/10.1097/ JGP.0b013e3181c53487.

80. Chen $R$, Hu Z, Wei $L$, et al. Severity of depression and risk for subsequent dementia: Cohort studies in China and the UK. Br J Psychiatry. Epub ahead of print 2008. DOl: https://doi.org/10.1192/bjp.bp.107.044974.

81. Mukku SSR, Dahale AB, Muniswamy NR, et al. Geriatric Depression and Cognitive Impairment_-An Update. Indian J Psychol Med. Epub ahead of print 2021. DOI: https://doi.org/10.1177/0253717620981556.

82. Lenze EJ, Rogers JC, Martire LM, et al. The association of late-life depression and anxiety with physical disability: A review of the literature and prospectus for future research. Am J Geriatr Psychiatry. Epub ahead of print 2001. DOI: https://doi.org/10.1097/00019442-200105000-00004.
83. Pellegrino LD, Peters ME, Lyketsos CG, et al. Depression in Cognitive Impairment. Curr Psychiatry Rep 2013; 15: 384

84. Vinkers DJ, Gussekloo J, Stek ML, et al. Temporal relation between depression and cognitive impairment in old age: Prospective population based study. Br Med J 2004; 329: 881-883.

85. McDermott LM, Ebmeier KP. A meta-analysis of depression severity and cognitive function. J Affect Disord 2009; 119: 1-8.

86. Muliyala KP, Varghese M. The complex relationship between depression and dementia. Ann Indian Acad Neurol; 13. Epub ahead of print 2010. DOI: https://doi.org/10.4103/0972-2327.74248.

87. Nakamura K, Kitamura K, Watanabe $Y$, et al. Rural-urban differences in the prevalence of cognitive impairment in independent communitydwelling elderly residents of Ojiya city, Niigata Prefecture, Japan. Environ Health Prev Med. Epub ahead of print 2016. DOI: https://doi. org/10.1007/s12199-016-0542-2.

\section{Publisher's Note}

Springer Nature remains neutral with regard to jurisdictional claims in published maps and institutional affiliations.

\section{Ready to submit your research? Choose BMC and benefit from:}

- fast, convenient online submission

- thorough peer review by experienced researchers in your field

- rapid publication on acceptance

- support for research data, including large and complex data types

- gold Open Access which fosters wider collaboration and increased citations

- maximum visibility for your research: over $100 \mathrm{M}$ website views per year

At BMC, research is always in progress.

Learn more biomedcentral.com/submissions 